\title{
Rediscovery and lectotypification of Lepidagathis diffusa (Acanthaceae), an endemic species from southern India
}

\author{
N. Dhatchanamoorthy ${ }^{1 *}$, N. Balachandran ${ }^{2}$ and K. Ravikumar ${ }^{1}$ \\ ${ }^{1}$ National Herbarium of Medicinal Plants and Repository of Raw Drug, School of Conservation of Natural \\ Resources, Trans Disciplinary University (TDU), Foundation for Revitalisation of Health Traditions (FRLHT), \\ 74/2, Jarakabande Kaval, Yelahanka, Bangalore - 560064, Karnataka, India. \\ ${ }^{2}$ Ecology Department, French Institute of Pondicherry, 11, Saint Louis Street, Puducherry - 605001, India. \\ *E-mail: dhatcha@gmail.com
}

\begin{abstract}
Lepidagathis diffusa C.B. Clarke, a species endemic to Karnataka and Tamil Nadu states in southern India, has been rediscovered after a century from Dharmapuri district in Tamil Nadu and also the name is lectotypified here.
\end{abstract}

Keywords: Barleria diffusa, Eastern Ghats, Endemic, Lectotype, Lepidagathis diffusa, Rediscovery

\section{Introduction}

The genus Lepidagathis Nees was earlier placed in tribe Barlerieae (Lindau, 1903; Kameyama, 2008). However, Scotland \& Vollesen (2000) segregated Lepidagathis and placed under the subtribe Barleriinae of the tribe Ruellieae based on molecular studies, pollen morphology, corolla aestivation and other morphological characters. At present, this Old World genus comprises of 71 species and 1 variety (The Plant List, 2015). In India, the genus is represented by 23 species and 8 varieties, of which 15 species are endemic to Western and Eastern Ghats of southern India (Nayar et al., 2014; Singh et al., 2015), and 12 species and 1 variety are found in Tamil Nadu (Kumari, 1987; Karthikeyan et al., 2009).

The present article lectotypifies the name L. diffusa, as well as reports the rediscovery of this species after a century from Palacode in Dharmapuri district of Tamil Nadu and Kollegal, Mysuru district of Karnataka, which are near to the type locality. Vajravelu (1990) and Kameswara Rao et al. (2003) assessed it as "Indeterminate" as information on the occurrence of this species are insufficient.

\section{Lectotypification}

In 1871, Robert Wight collected a specimen from the Deccan Peninsula and named it as "Barleria diffusa Wight" (K000950052), but did not publish the name. In May 1880, Beddome collected a specimen (K000950051) in Bellary (Karnataka) and identified the specimen as Lepidagathis. Clarke (1885) described it as L. diffusa based on the two collections and treated " $B$. diffusa" as an invalid name. The Plant List (2015) database treats "Barleria diffusa Wight ex C.B. Clarke" as an unresolved name (not committing whether the name is accepted or a synonym). Some of the publications from Karnataka (Saldanha, 1984; Singh, 1998) and Tamil Nadu (Henry et al., 1987; Karthikeyan et al., 2009) treated L. diffusa C.B. Clarke as the valid name. It is evident from the protologue of Lepidagathis diffusa that Clarke cited two specimens, and hence one of the befitting specimens has been designated here as the lectotype in accordance with Art. 9.2 and 9.5 of Melbourne Code (McNeill et al., 2012).

Lepidagathis diffusa C.B. Clarke in Hook.f., Fl. Brit. India 4: 518. 1885; Gamble, Fl. Madras: 1067. 1923; N.P. Singh, Fl. E. Karnataka 2: 498. 1998; Karthik. et al., Fl. Pl. India 1: 30. $2009 . \quad$ Fig. 1

Lectotype (designated here): INDIA, Deccan Peninsula, s. die, R. Wight s.n. (K000950052, image!).

Barleria diffusa Wight ex C.B. Clarke in Hook.f., Fl. Brit. India 4: 518. 1885, pro syn. (nom. inval.).

Herb, perennial, to $50 \mathrm{~cm}$ high, rarely prostrate; matured branchlets glabrous. Stems densely hispid appressed-hairy when young. Leaves linear-lanceolate or oblong-oblanceolate, 15-20 × 

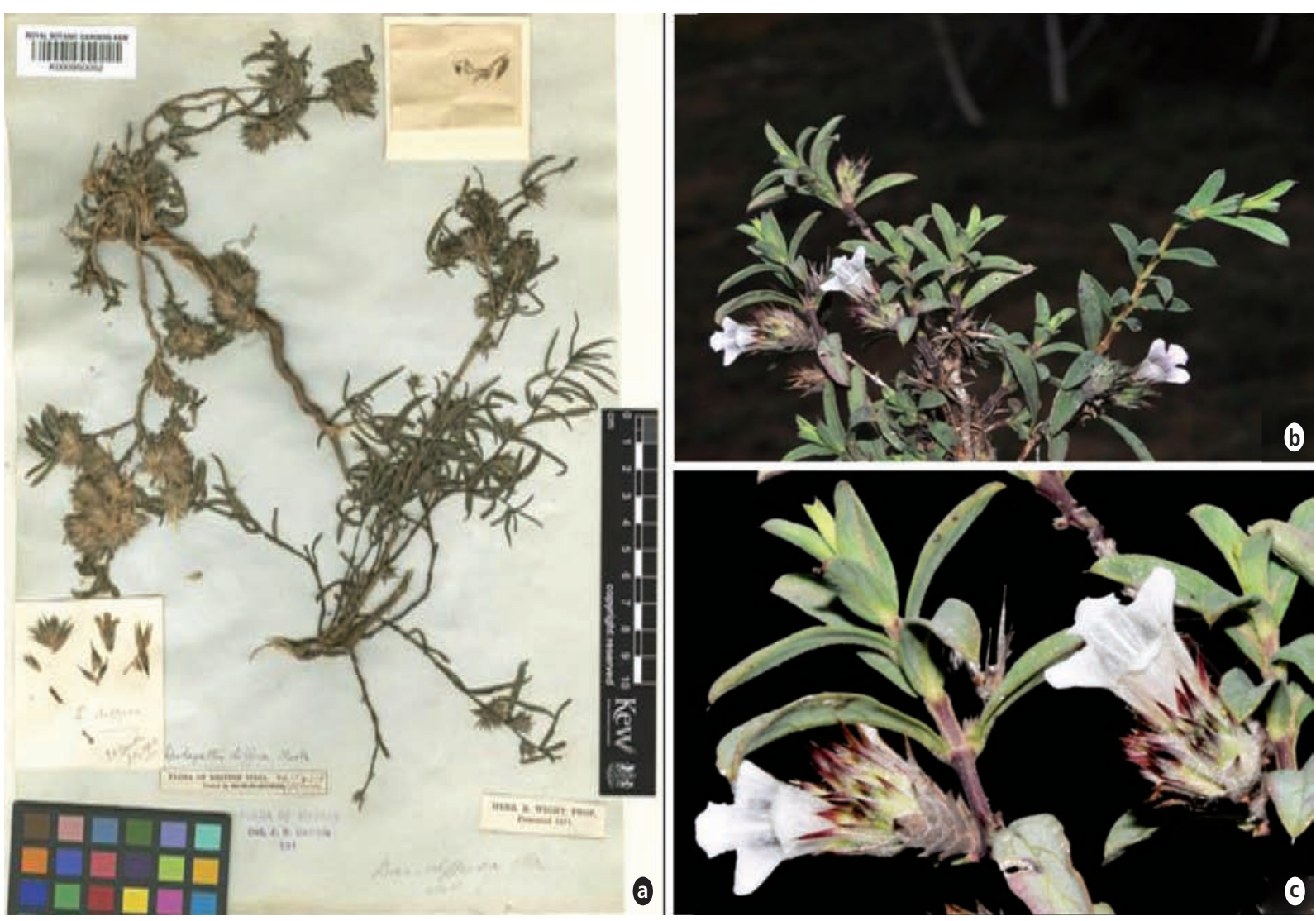

Fig. 1. Lepidagathis diffusa C.B. Clarke: a. Lectotype (R. Wights.n., K000950052); b. Flowering-twig; c. Flowering-twig.

3-5.2 $\mathrm{mm}$, sessile, base attenuate, margins entire, minutely ciliate, apex mucronate or spinescent; lateral veins $4-6$, densely hispid appressed-hairy on both surfaces. Inflorescences spike, 1.5-3 $\times$ $1-1.3 \mathrm{~cm}$. Flowers $2-2.5 \mathrm{~cm}$ across, pinkish purple; bracts lanceolate, 5-12 $\times 1-3 \mathrm{~mm}$, margins densely silky-ciliate, apex acuminate or spinescent, longsilky-hairy outside, long- or short-silky-hairy inside. Calyx slightly unequally 4-partite; outer 2 lanceolate, c. $6 \mathrm{~mm}$ long; inner 2 lanceolate, $c$. $5 \mathrm{~mm}$ long, villous-silky. Corolla 1-1.5 cm long; upper lip ovate, c. $6 \mathrm{~mm}$ long, 2-lobed; lower lip obovate, c. $8 \mathrm{~mm}$ long, 3-lobed, apex obtuse; upper side densely silky-hispid-hairy; inner side sparsely silky-hispid-hairy. Stamens 4; filaments flat, 2-5 $\mathrm{mm}$ long; anthers oblong, c. $3 \mathrm{~mm}$ long. Capsules ovoid-oblong, c. $3.5 \times 2.3 \mathrm{~mm}$, glabrous; seeds 4 , ovoid-oblong, hairy.

Flowering \& fruiting: September-November.

Habitat: Dry localities with red loamy soil mixed with gravels.

Distribution: Karnataka and Tamil Nadu. Endemic.

Specimens examined: INDIA, Karnataka: Mysuru district, Kollegal, 28.1.1984, Ramesh \& Deshays s.n.
(Acc. No. 0302) (HIFP). Tamil Nadu: Dharmapuri district, Palacode, Belamarapatti village, $670 \mathrm{~m}$, 25.10.2013, N. Dhatchanamoorthy 118161 (FRLH); Palacode, Belamarapatti village, $670 \mathrm{~m}$, 19.9.2015, N. Dhatchanamoorthy \& N. Balachandran s.n. (Acc. No. 26995) (HIFP).

Note: It grows along with Andrographis serpyllifolia (Vahl) Wight, Aristida setacea Retz., Corbichonia decumbens (Forssk.) Exell, Crotalaria angulata Mill., Euphorbia thymifolia L., Oldenlandia umbellata L., Indigofera linnaei Ali, I. linifolia (L.f.) Retz., Mollugo nudicaulis Lam., Senna italica Mill., Trianthema triquetra Rottler \& Willd., Tribulus lanuginosus L. and T. subramanyamii P. Singh et al.

\section{Rediscovery}

Lepidagathis diffusa is a perennial herb, endemic to southern India (Karnataka and Tamil Nadu). During a recent plant exploration in Dharmapuri district (Palacode, Belamarapatti village) of Tamil Nadu, a population of this species consisting only 13 individuals were found within a radius of 500 $\mathrm{m}$. Consultation of $\mathrm{MH}$ and $\mathrm{RHT}$ revealed that this species was not re-collected during the recent past! So, the present collection is the rediscovery of this 
species after 142 years from places near to its type locality. To assess the current threat status of this species, a thorough survey should be conducted in and around the type locality as well as in similar habitats in the entire southern India to assess the extent and area of occurrence, population size and threats.

\section{Acknowledgements}

Authors are thankful to Dr. Kanchi N. Gandhi, Senior Nomenclatural Registrar, Harvard University, USA, for his valuable comments and inputs on this manuscript; Dr. G.V.S. Murthy, Head of Office, Botanical Survey of India, Southern Regional Centre, Coimbatore, for granting permission to consult the Madras Herbarium; Dr. B.R. Ramesh, Director of Research for granting permission to examine the HIFP specimen; the Director of FRLH and Mr. D.K. Ved, IFS (Retd.), Advisor, for providing the facilities.

\section{Literature Cited}

Clarke, C.B. 1885. Lepidagathis. In: Hooker, J.D. (ed.), The Flora of British India. Vol. 4. L. Reeve \& Co., London. pp. 515-523.

Gamble, J.S. 1923. Flora of the Presidency of Madras. Part VI (Scrophulariaceae to Plantaginaceae). Adlard \& Son, London.

Kumari, G.R. 1987. Acanthaceae. In: Henry, A.N., Kumari, G.R. \& V. Chithra (eds.), Flora of Tamil Nadu, India. Vol. 2, Ser. I: Analysis. Botanical Survey of India, Southern Circle, Coimbatore. pp. 138-162.

Kameswara Rao, C., Geetha, B.L. \& G. Suresh 2003. Red list of Threatened Vascular Plant Species in India. Compiled from the 1997 IUCN Red List of Threatened Plants. ENVIS, Botanical Survey of India, Kolkata.

Kameyama, C. 2008. New species, nomenclatural change and lectotypifications in Neotropical Lepidagathis Willd. (Acanthaceae). Kew Bull. 63: 565-581.

Karthikeyan, S., Sanjappa, M. \& S. Moorthy 2009. Flowering Plants of India. Vol. I. Dicotyledons (Acanthaceae-Avicenniaceae). Botanical Survey of India, Kolkata. pp. 30-32.

Krishnamurthy, K.V., Murugan, R. \& K. Ravikumar 2014. Bioresources of The Eastern
Ghats. Bishen Singh Mahendra Pal Singh, Dehra Dun.

Lindau, G. 1903. Acanthaceae. In: Chodat, R. \& E. Hassler (eds.), Plantae Hasslerianae. Bull. Herb. Boissier Ser. II, 3: 628-634.

McNeill, J., Barrie, F.R., Buck, W.R., Demoulin, V., Greuter, W., Hawksworth, D.L., Herendeen, P.S., Knapp, S., Marhold, K., Prado, J., Prud'homme van Reine, W.F., Smith, J.F., Wiersema, J.H. \& N.J. Turland (eds.) 2012. International Code of Nomenclature for algae, fungi and plants (Melbourne Code). Adopted by the Eighteenth International Botanical Congress Melbourne, Australia, July 2011. Regnum Veg. 154. Koeltz Scientific Books, Königstein.

Nayar, T.S., Rasiya Beegam, A. \& M. Sibi 2014. Flowering Plants of the Western Ghats, India. Vol. 1. Dicots. Jawaharlal Nehru Tropical Botanic Garden and Research Institute, Thiruvananthapuram.

Profice, S.R., Kameyama, C., Cortes, A.L.A., Braz, D.M., Indriunas, A., Vilar, T., Pessoa, C., Ezcurra, C. \& D. Wasshausen 2015. Acanthaceae in Lista de Especies da Flora do Brasil. Jardim Botanico do Riode Janeiro.

Saldanha, C.J. 1984. Flora of Karnataka. Oxford \& Science Publishing Co., New Delhi.

Scotland, R.W. \& K. Vollesen 2000. Classification of Acanthaceae. Kew Bull. 55: 513-589.

Singh, N.P. 1998. Flora of Eastern Karnataka. Vol. 2. Mittal Publications, Delhi. pp. 497-498.

Singh, P., Karthigeyan, K., Lakshminarasimhan, P. \& S.S. Dash 2015. Endemic Vascular Plants of India. Botanical Survey of India, Kolkata.

The Plant List, 2015. Version 1.1. Published on the internet; http://www.theplantlist.org/. (Accessed on 15th December 2015).

Vajravelu, E. 1990. Lepidagathis diffusa Clarke. In: Nair, M.P. \& A.R.K. Sastry (eds.), Red Data Book of Indian Plants. Vol. 3. Botanical Survey of India, Calcutta.

Received: 16.2.2016

Revised and Accepted: 22.12.2017 